\title{
Improving radiotherapy in cancer treatment: Promises and challenges
}

\author{
Helen H.W. Chen ${ }^{1}$ and Macus Tien Kuo ${ }^{1,2}$ \\ ${ }^{1}$ Division of Clinical Radiation Oncology, Department of Radiation Oncology, National Cheng Kung University Hospital, \\ Department of Radiology, College of Medicine, National Cheng Kung University, Tainan, Taiwan \\ ${ }^{2}$ Department of Translational Molecular Pathology, The University of Texas MD Anderson Cancer Center, Houston, Texas, USA \\ Correspondence to: Macus Tien Kuo, email: tkuo@mdanderson.org \\ Helen H.W. Chen, email: helen@mail.ncku.edu.tw
}

Keywords: radiotherapy, DNA damage response, hypoxia, cancer genomics, immune check points

Received: February 03, $2017 \quad$ Accepted: April 18, $2017 \quad$ Published: June 08, 2017

Copyright: Chen et al. This is an open-access article distributed under the terms of the Creative Commons Attribution License 3.0 (CC BY 3.0), which permits unrestricted use, distribution, and reproduction in any medium, provided the original author and source are credited.

\section{ABSTRACT}

Effective radiotherapy for cancer has relied on the promise of maximally eradicating tumor cells while minimally killing normal cells. Technological advancement has provided state-of-the-art instrumentation that enables delivery of radiotherapy with great precision to tumor lesions with substantial reduced injury to normal tissues. Moreover, better understanding of radiobiology, particularly the mechanisms of radiation sensitivity and resistance in tumor lesions and toxicity in normal tissues, has improved the treatment efficacy of radiotherapy. Previous mechanism-based studies have identified many cellular targets that can affect radiation sensitivity, notably reactive oxygen species, DNA-damaging response signals, and tumor microenvironments. Several radiation sensitizers and protectors have been developed and clinically evaluated; however, many of these results are inconclusive, indicating that improvement remains needed. In this era of personalized medicine in which patients' genetic variations, transcriptome and proteomics, tumor metabolism and microenvironment, and tumor immunity are available. These new developments have provided opportunity for new target discovery. Several radiotherapy sensitivity-associated "gene signatures" have been reported although clinical validations are needed. Recently, several immune modifiers have been shown to associate with improved radiotherapy in preclinical models and in early clinical trials. Combination of radiotherapy and immunocheckpoint blockade has shown promising results especially in targeting metastatic tumors through abscopal response. In this article, we succinctly review recent advancements in the areas of mechanism-driven targets and exploitation of new targets from current radio-oncogenomic and radiation-immunotherapeutic approaches that bear clinical implications for improving the treatment efficacy of radiotherapy.

\section{INTRODUCTION}

Radiotherapy is used in at least two-thirds of cancer treatment regimens in Western countries, and remains an important curative treatment modality for uncomplicated locoregional tumors. Over the past few decades, substantial technological advancement in 3D conformal radiation treatments, such as stereotactic (body) radiotherapy (SBRT), intensity-modulated radiation therapy (IMRT) and improved imaging systems (i.e., image-guided radiation therapy, IGRT), have enabled precise delivery of matching radiation doses to the exact dimensions of tumor while minimizing radiation exposure of surrounding normal tissue (see recent review [1]). These state-of-the-art technological advancements, together with a better understanding of tumor biology at the molecular, cellular, and physiological and immunological levels, have improved the treatment 
efficacy of radiotherapy. For example, the overall survival rates of cancer radiation therapy have improved from about $30 \%$ two decades ago to about $80 \%$ nowadays in some malignancies such as head and neck cancers [1, 2]. However, many tumor types remain insensitive to radiotherapy owing to intrinsic resistance or recur shortly after the treatment because of acquired resistance. Cancer stem cells are considered to be the primary source of radiation- and chemo-resistace, and tumor heterogeneity plays important role in acquired radiation resistance, indicating that radiotherapy still needs to improve [3].

Traditionally, cancer radiotherapy is limited by the maximum tolerated dose to adjacent normal tissues. Thus, effective radiotherapy is considered in terms of how to maximize cancer cell killing capacity within the capacity of acceptable dose that adjacent healthy tissues can tolerate from radiation injury. As cancer is a heterogeneous disease consisting of genetic, architectural, metabolic, pathophysiologic, and immunologic complexities, tremendous efforts have been devoted to identifying biomarkers associated with intrinsic and acquired radioresistance. In the past two decades, many radiation sensitizers and protectors have been identified, allowing radiotherapy to evolve from the traditionally prescribed "one-size-fits-all" concept [4] to a more dynamic and patient-tailored treatment modality.
In the era of personalized medicine that patients' DNA-sequencing and RNA-sequencing data can be precisely determined at the single-cell level. Moreover, new technologies have allowed precisely profiling of protein expression and immune system. These technical advancements enable the realization that tumor cells are highly heterogeneous at the individual patient basis. Using these datasets, radiation oncologists have a large armamentarium with which to develop novel radiation sensitivity markers for improving treatment efficacy. Personalized cancer therapy has been successfully delivered in targeted chemotherapy of chronic myelogenous leukemia with imatinib which targets the BCR-ABL oncoprotein [5]. Other great achievements include the identification of the BRAF mutation as driver in malignant melanoma and the development of vermurafenib which targets BRAF-mutant tumors [6]. Moreover, recent advances in targeted immune checkpoint therapy have firmly established immunotherapy as the fourth pillar in cancer therapy, alongside surgery, chemotherapy and radiotherapy (Figure 1). Radiation can contribute to the alterations of specific and systemic antitumor immune responses, especially for metastatic disease [7]. Therefore, radiation oncology can benefit from cross-fertilizing with other forms of therapy.

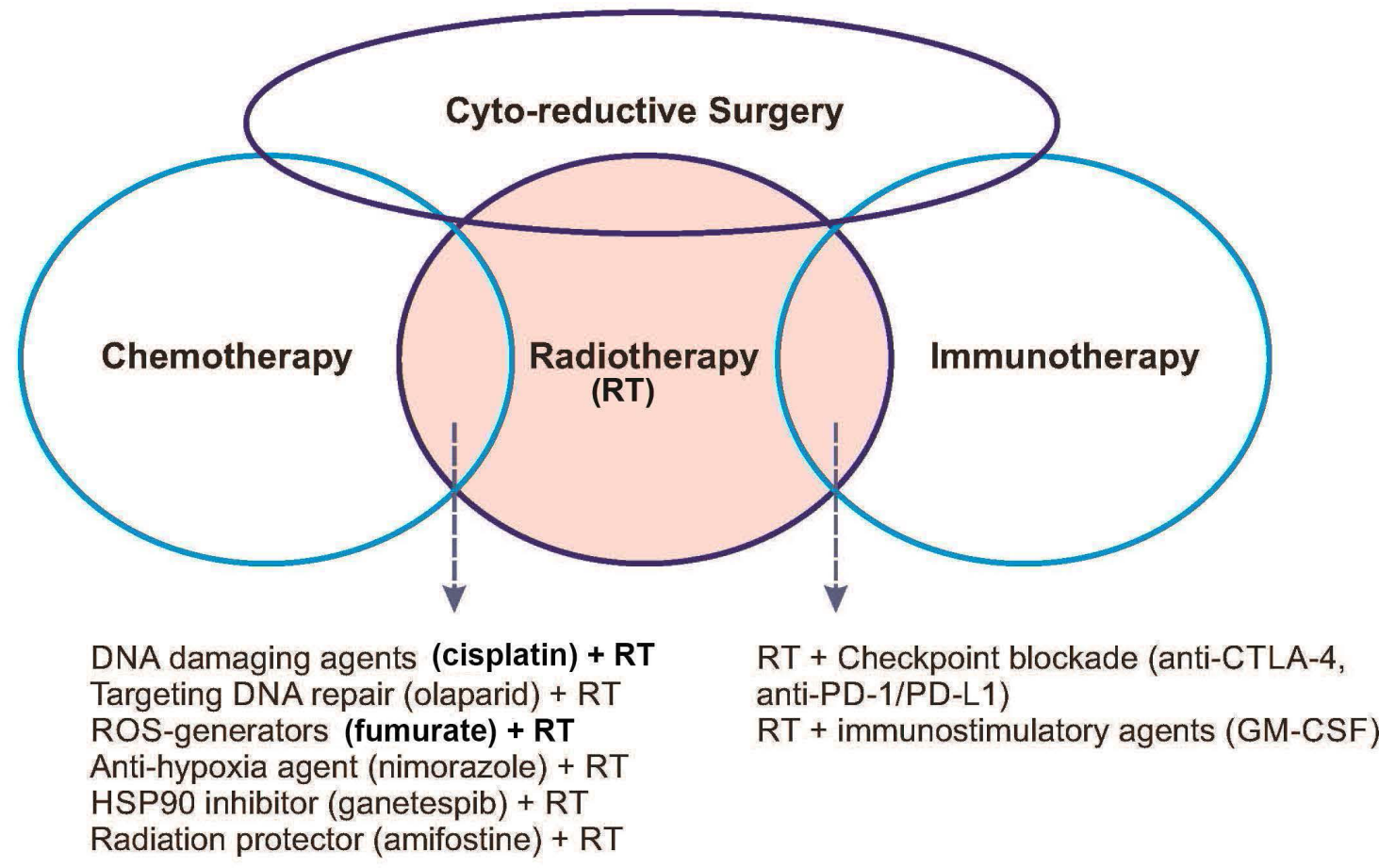

Figure 1: Schematic diagram showing the interrelationships among the four pillars of current cancer therapy, i.e., cyto-reductive surgery, chemotherapy, radiotherapy, and immunotherapy. Cyto-reductive surgery is used to debulk tumor mass for subsequent three other treatment types. Radiotherapy is used in combination with many other therapies as indicated in the overlapping areas. 
In this review, we will describe recent advancements in radiotherapy research in multiple areas, including known radiosensitivity markers such as reactive oxygen species (ROS), DNA repair, tumor microenvironment, as well as newer strategies that integrate cancer genomics/ epigenetics and immunology. We keep in mind that preclinical studies are not always clinically sustainable; for example, EGFR inhibitors which have demonstrated synergy with radiation in preclinical studies [8, 9], but failed to so in phase III clinical trials $[10,11]$. We will provide an overview of the promises and challenges of current radiotherapy, with a focus on research that is at the stages of clinical validation or has clinical potentials.

\section{IMPROVING TUMOR ELIMINATION BY TARGETING KNOWN RADIATION SENSITIVITY BIOMARKERS}

\section{Targeting reactive oxygen species}

Ionizing radiation rapidly induces water radiolysis products inside cells, which triggers ROS production [12] (Figure 2). ROS, especially hydroxyl radicals (.OH), play important roles in causing DNA damages and other radiation-induced injury. Mitochondria, which consume about $90 \%$ of the body's oxygen, are the major source of
ROS production, mainly from leakage of electrons from the electron transfer chain (complexes I and III, and to a lesser extent complex II) [13]. Radiation-induced ROS production can derive from mitochondria which increases with oxygen tension [14]. Radiation can also induce ROS by activating the cytosolic Rac1/NADPH oxidase system $[15,16]$. Cellular redox conditions are regulated by the balance between anti-oxidants and pro-oxidants performed by a host of redox enzymatic reactions. Many preclinical studies have demonstrated that depleting or inhibiting intracellular antioxidants (glutathione, thioredoxin, peroxiredoxin and superoxide dismutase, etc.) can enhance radiation sensitivity; and, in contrast, upregulation of these redox-regulating enzymes can protect radiation damage [17].

Another important pathway involved in protecting radiation-induced oxidative stress is the Kelch-likeECHassociated protein 1-nuclear factor erythroid 2-related factor 2 (KEAP1-NRF2) system. NRF2 is a master regulator of phase II detoxifying and antioxidant genes. Under normal conditions, NRF2 is bound by the adapter protein KEAP1, which recruits the CUL3 ubiquitin ligase, leading to proteasomal degradation of NRF2. During radiation-induced oxidative stress, NRF2 is released from KEAP1, translocates into the nucleus, and transcriptionally upregulates genes involved in anti-ROS functions. Deletion of Keapl promotes tumor aggressiveness in

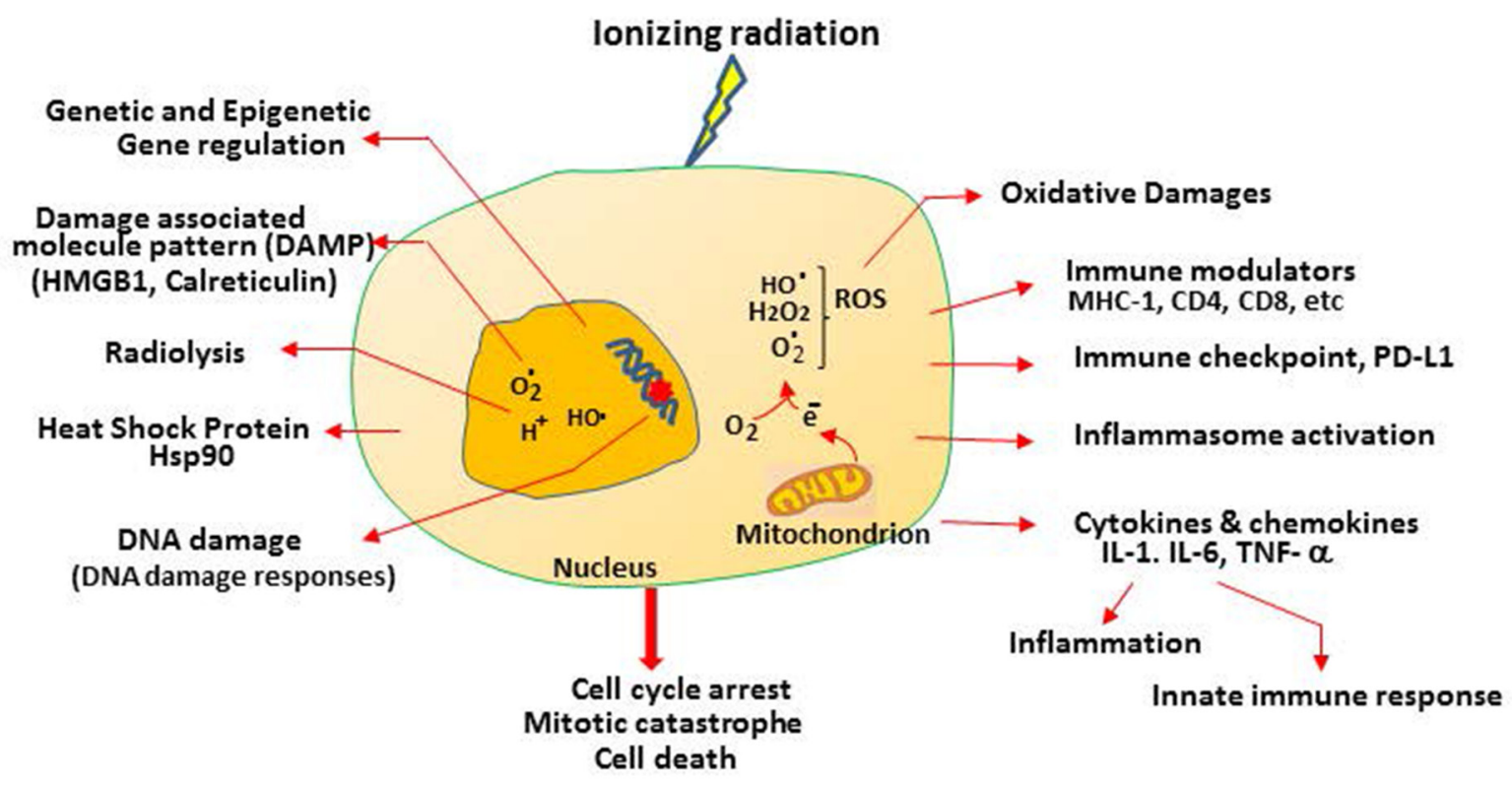

Figure 2: Multiple features of radiation-induced cellular responses in cancer cells. Radiation induces radiolysis which "splits" $\mathrm{H}_{2} \mathrm{O}$ into radicals. This can occur throughout the cells, but for simplicity, only inside the nucleus is indicated. Radiation induces mitochondrial leakage of electrons which interact with $\mathrm{O}_{2}$ to generate ROS. ROS can travel into nucleus to cause DNA damage and induce oxidative stress. Other cellular responses include immune modulators, checkpoint, cytokines, inflammation, and DNA damage responses, released tumor antigens and danger signals such as HMGB1 and calreticulin as described in the text. 
animal models and shows resistance to radiotherapy. Moreover, KEAP1/NRF2 mutations are associated with increased risk of local recurrence after radiotherapy in non-small cell lung cancer (NSCLC) patients [18]. Clinical studies have demonstrated correlations between expression of these redox enzymes and poor prognosis of radiation-treated early-stage invasive breast cancer [19].

Several ROS modulators including 2-deoxyD-glucose and 6-aminonicotinamide [20], curcumin [21] and parthenolid [22] have been demonstrated to enhance relative intracellular redox status. Among these, curcumin has been in several clinical trials as a radiation modulator in treating prostate cancer (NCT1749323) and breast cancer (NCT02724618). Dysregulation of cancer metabolism can also alter cellular ROS status. Germline mutations in the fumarate hydratase $(F H)$ gene predispose individuals to hereditary leiomyomas and renal cell cancer (HLRCC), which occurs in about $20 \%$ of overall renal cell carcinoma (RCC) [23]. The encoded enzyme catalyzes fumarate-to-malate conversion in the TCA cycle. RCC is characterized by fumarate accumulation which promotes the conjugation between fumarate and glutathione, resulting in enhanced ROS production that can be inhibited by the antioxidant, $\mathrm{N}$-acetylcysteine [24, 25]. Cultured cell models have shown that membrane-permeable fumarate (dimethyl fumarate) can enhance radiosensitivity [26, 27]. Although RCC has been conventionally considered radiation resistant, recent clinical studies have shown promising results in primary [28] and metastatic RCC [29]. It would be of interest to investigate whether HLRCC and RCC patients with mutations in FH are particularly sensitive to radiotherapy.

Likewise, free radical scavengers/antioxidants have been developed as radioprotective agents. So far, amifostine (WR2721) is the only radioprotector approved by the US Food and Drug Administration (FDA) specifically in clinical settings to reduce the incidence and severity of acute and chronic xerostomia of patients with head and neck squamous carcinoma without affecting the efficacy of radiation [30]. Amifostine is a sulfhydrylphosphorylate compound. Upon dephosphorylation by alkaline phosphatase which is preferentially expressed in normal tissues relative to neoplastic counterparts, it is converted into an active metabolite, WR-1065, a free radical scavenger and protector of radiation-induced DNA damages [31]. However, despite its current clinical application, its disadvantages in toxicity and limited route of administration indicate that additional development is needed.

Inflammation is intimately associated with tumor development and progression [32]. Inflammation can promote radiation sensitivity. Inflammasomes, a group of multiprotein complexes consisting of NLRP3, NLRC4, NLRP6, and AIM2, are sensed by a variety of inflammation-inducing stimuli including ROS, to mediate caspase-dependent activation of cytokines
[33, 34], leading to a programmed lytic cell death pathway called "pyroptosis". This is thought the initial host defense mechanism against infection by exposing intracellular pathogens to the innate immune system [35]. Inflammasomes (Nlrp3, caspase 1 et al) are significantly induced in the lung of mice by irradiation, and induced inflammasomes accelerate radiation-induced inflammation and pneumonitis and fibrosis in animal model [36]. Nlrp 3-cells are resistant to radiation-induced DNA damage [37], and so are mice lacking caspase 1. ROS-induced DNA damage can be sensed by the AIM2 inflammasome, which senses double-stranded DNA breaks $[38,39]$. Aim ${ }^{-1}$ mice exhibit intestinal protection from lethal effects by subtotal body irradiation [40]. These findings suggest that targeting these inflammasomes may be an effective strategy for cytoprotection against radiation-induced lethality.

\section{Targeting radiation-induced DNA damage response signaling}

Radiation-induced DNA damage of normal tissues, if not properly repaired, contributes to the major mechanism of cell death [41]. Mechanisms of radiation-induced DNA damage and repair have been extensively investigated over the past two decades [42, 43]. Radiation-induced DNA damage includes abasic lesions, deoxyribose ring opening, single-stranded breaks and double-stranded breaks (DSB). Different sensing mechanisms are involved in different types of DNA damage responses (DDRs). Ataxia telangiectasia mutated (ATM), together with MRE11-RAD50 and the NBS1 complex are the earliest responders to DSB. Cells and animal models have demonstrated that defective breast cancer gene 1/2 (BRCA1/2) which encodes the repair system for DNA DSB is involved in radiation resistance. Clinical trials showed that breast cancers with BRCA1 (-/-) exhibit elevated sensitivity to radiation therapy [44].

Single-stranded breaks are recognized by poly(ADP-ribose) polymerase 1 (PARP1) for the synthesis of a poly-(ADP-ribose) chain for recruiting the factors X-ray cross-complementing protein 1 (XRCC1) and DNA polymerase $\beta$ (Pol $\beta)$ for DNA repair. Several targeting PARP agents are at various stages of clinical development [43]. Olaparib, an anti-PARP1 agent, has been approved by the FDA for treating ovarian and breast cancers with $B R C A$ mutations, often in combination with platinum-based chemotherapy [45]. Olaparib resistance due to upregulation of multidrug resistance drug efflux mechanism which eliminate olaparib and also due to secondary mutation of BRCA2, are frequently associated with olaparib failure [43]. It has been tested in clinical trials in combination with radiotherapy against NSCLC, breast cancer, and head and neck cancer. Another PARP inhibitor rucaparib was approved by the US FDA for treating ovarian cancers in December, 2016 [46]. 
Pitroda et al reported that reduced expression of a four-gene signature involved in DNA repair pathway (Rif1, PARI, RAD51, and $K u 80$ ) is associated with reduced patient survival rates and adverse clinical features in breast cancer and NSCLC [47]. Heat-shock protein 90 (Hsp90), which is involved in correcting protein misfolding of its client proteins, directly regulates about 725 client proteins, many of them are related to DDR signaling, e.g., ATM, NBS1, and ATR [48]. In addition, numerous publications have indicated that inhibition of Hsp90 results in radiation sensitization in cultured cell models ([49, 50] and references therein). The Hsp90 inhibitor, ganetespib, has been in clinical trials as a radiosensitizer in rectal cancer (NCT01554969) and esophageal cancer (NCT02389751). Ganetespib is safe and well-tolerated, lacking cardiac, liver and ocular toxicity. It has the potential to become the first-in-kind Hsp90 inhibitor to be approved as a radiosensitizer [51]. On the whole, after many years of research, it appears that targeting DDR signaling remains a viable approach for improving radiation sensitivity.

\section{Targeting tumor hypoxia}

Hypoxia is a hallmark of solid tumors due to their poor vascularity, and is associated with poor prognosis in many types of cancers, including cervical carcinoma [52], head and neck cancer [53], and sarcomas [54]. Hypoxia is associated with increased chemoresistance, genomic instability, and tumor invasion and metastasis [55]. It was estimated that hypoxic cells can be up to three times more resistant to radiation-induced damage than aerobic cells are $[53,56]$. Hypoxic tumors can be detected using the FDA approved fluorine-18 fluoromisonidazole by positron emission tomography. Hypoxic radiosensitizers such as hyperbaric oxygen, carbogene breathing and nitroimidazoles [57] have been tested in clinics to sensitize radiation and have been associated with improved locoregional control and disease-free survival compared with radiation alone for head and neck squamous cell carcinoma (HNSCC) [58].

Nimorazole, a radiosensitizer by fixation of radiation-induced damage under hypoxic conditions [59], has showed improved the 5-year actuarial rate of locoregional control of HNSCC from 33\% (placebo) to $49 \%$ [60] in a randomized Danish trial. It has thus been adopted for routine clinical use in head and neck cancer patients in Denmark. However, results from other phased III trials were not as impressive [61]. The use of DNA-damaging agent cisplatin in a nimorazole and radiation combination trial showed additional improvement of HNSCC to $80 \%$ [62]. Tirapazamine (TPZ) has been shown to preferentially kill hypoxic cells because of its activation under low $\mathrm{O}_{2}$ conditions [63]. TPZ has been shown to enhance cisplatininduced cell killing in a mouse tumor model, however, a phase III trial (TPZ, cisplatin, and radiation versus cisplatin and radiation) for HNSCC showed no evidence of improved overall survival with TPZ [64]. Thus, despite many years of exploratory studies, it appears that targeting hypoxia for radiation sensitization using hypoxia modifiers has yet to produce clinical impact and further investigation remains needed.

\section{IMPROVING RADIOTHERAPY BY EXPLOITING NEW TARGETS IN CANCER GENOMICS}

\section{Identifying a gene signature for radioresponse prediction}

Recent advances in genomic analyses in patients have brought precision oncology close to reality. This development has been primarily due to the affordable next-generation sequencing (NGS) and advancement in bioinformatics. NGS has been routinely incorporated into clinical care. For example, in a recent study of 213 patients with HNSCC who have been followed routine care including surgery, definitive radiation, or definitive chemoradiation. It was found that PIK3CA amplification (but not mutations) and RAS mutations were associated with poorer outcomes [65]. In another study, molecular profiling of 151 advanced and treatment-resistant HNSCC cases using an NGS platform identified actionable targets that may guide treatment decision-making [66]. Recent large-scale genome-wide association studies and largescale replication genotyping identified more than 90 breast cancer susceptibility loci $[67,68]$. Patients with genetic association with high polygenic risk of breast cancer have no increased risk of developing late or acute radiotherapy toxicity [68].

In another radiotherapy study, 58 prostate cancer patients without prior treatment received IMRT with a targeted dose of 61 to 72 Gy. This study identified 19 genes with elevated steady-state mRNA levels that were correlated with radiation-resistance. Most of these genes are in the DSB repair pathway [69]. Eschrich et al developed a radiation sensitivity molecular signature based on gene expression profiling datasets and identified 10 genes out of an original pool of more than 7000 genes. This signature has been validated in 5 independent cohorts of 621 breast cancer patients [70]. Similarly, Zhao et al [71] developed a 24-gene post-operative radiotherapy outcomes score (PORTOS) for monitoring the likelihood of developing postoperative radiotherapy metastasis at 10 years in patients with prostate cancers. It was found that patients with high PORTOS were less likely to have metastasis at 10 years than those who did not receive radiotherapy.

In addition to transcriptional regulation, there is evidence that epigenetic mechanisms are also involved in radiosensitivity. Ahmed et al. reported that elevated expression of $\mathrm{O}(6)$-methylguanine-DNA methyltransferase 
(MGMT) is significantly associated with radiosensitivity in a subset of glioblastomas [72]. In a prostate cancer cell model, it was reported that irradiation caused durable upregulation of cancer stem cell marker proteins, including aldehyde dehydrogenase 1A1 (ALDH1A1) as well as long-term altered histone methylation patterns of $\mathrm{H} 3 \mathrm{~K} 4$, H3K36, and H3K27 tri-methylation [73]. Alterations in epigenetic marks play a substantial role in radiation response and in fibrosis development (see below) [74].

\section{Identifying radiation toxicity genes in normal tissues}

Radiation toxicities in normal tissues include acute radiotoxicity and late complications such as telangiectasia, edema, and fibrosis. Of particular importance is radiationinduced fibrosis, a late event usually occurs 4 months to several years after radiation. Fibrosis can occur in many organs depending on dose, volume of irradiated tissue, and types of tissue exposed to irradiation. As the cancer patients has increased survival time, this can significantly deteriorate quality of life or even causes death [74]. Radiation-induced fibrosis has been proposed to follow a mechanism similar to that of chronic wound healing processes $[75,76]$. Radiation-induced fibrosis is considered to arise from complex molecular signaling involving cytokines, growth factors, integrins and cell adhesion, stress response and DDR, and extracellular matrix remodeling, resulting in the formation of altered cell architecture called myofibroblasts [74].

Several studies have described differences in gene expression profiles between samples derived from patients with and without radiation-induced fibrosis using patients-derived fibroblasts in cultures $[77,78]$ or peripheral lymphocytes $[79,80]$. However, these studies have not generated confirmatory "gene expression signatures" for predicting radiation-induced fibroblasts. Recently, in a gene expression profiling of whole blood from breast cancer survivors with and without fibrosis 3-7 years after radiation therapy was published and 87 differentially expressed genes were identified, including genes downregulated during the maintenance phase of fibrosis as opposed to genes upregulated during the early, initiating phase of fibrosis. Genes involved in the TGF- $\beta 1$ signaling were frequently upregulated [81].

Several preclinical approaches have been designed to target radiation-induced fibrosis in various organ sites in mice, either by targeting matrix synthesis or by suppressing inflammation [76]. In one lung cancer model, it was found that TGF- $\beta 1$ receptor inhibitor LY2109761 showed reduction of radiation-induced inflammation and pulmonary fibrosis and prolonged survival [82]. These findings led to a phase I/II trial using stereotactic ablative radiotherapy in combination with anti-TGF- $\beta 1$ antibody (fresolimumab) in SCLC patients to investigate whether fresolimumab inhibits radiation-induced cytotoxicity
(NCT02581787). In a randomized clinical trial in which pentoxifylline and vitamin $\mathrm{E}$ were given for 6 months after breast wall irradiation, no difference in overall survival and disease-free survival was observed, however, fibrosis was significantly reduced in the treated group [83].

\section{RADIOTHERAPY, TUMOR RECURRENCE, AND CIRCULATING TUMOR CELLS}

Circulating tumor cells (CTCs) are rare cancer cells shed from primary or metastatic sites. One mechanism of cancer cells release into the circulation may be due to radiation-induced structural damage to blood vessels within the tumors. CTCs have provided non-invasive "liquid biopsies" for cancer molecular and immune diagnoses, and also real-time monitoring of treatment response that may guide the treatment options [84]. Several pre-clinical studies have shown that radiotherapy can enhance CTC production in animal models, and CTC density is an independent biomarker for poor prognosis in NSCLC [85], esophageal squamous cell carcinoma [86], and breast cancers [87]. This may be particularly relevant in the early stages of hypofractionated radiotherapy when accumulated radiation dose is not sufficient to kill most cancer cells, suggesting that hyperfractionated radiotherapy may be more effective in eliminating CTCs. Indeed, in a randomized controlled trial involving 563 NSCLC patients that were treated with a high-intense but brief regimen called continuous hyperfractionated accelerated radiotherapy (CHART) vs conventional prolonged radiotherapy. CHART regimen showed significant improvement in achieving local tumor control and survival than the conventional hypofractionated radiotherapy [88]. However, in another study, hyperfractionated radiotherapy showed no superiority to conventional radiotherapy in childhood medulloblastoma. These results suggest that radiotherapy efficacy may depend on fractionated schemes including tumor types and radiation schedules [89].

It has been reported that CTCs in the blood can re-colonize back at the original site, where cytokines are produced which serve as CTC attractants [90]. This "self-seeding" has been documented in breast cancer after irradiation, resulting in tumor recurrence after radiotherapy. Granulocyte-macrophage colony stimulating factor induced upon irradiation is one cytokine that stimulates tumor self-seeding [91]. It has been reported that about half of the breast cancer patients after conserving surgery and radiotherapy, have recurrence disease at the same site [92]. Although this tumor recurrence cannot be entirely due to CTCs, these observations suggest that CTCs play dual roles in tumor dissemination and tumor recurrence after radiation.

Advances in DNA-sequencing and RNAsequencing technologies at the single-cell level have 
made CTCs important cell sources for genomic landscape profilings. Although the utility of liquid biopsy analysis for biomarker identifications in radiotherapy sensitivity/ resistance and radiation toxicity remains to be established, it is conceivable that CTCs will play an important role in this area.

\section{IMPROVING RADIATION SENSITIVITY THROUGH MODULATION OF TUMOR IMMUNITY}

\section{Radiation and general immune response}

Radiotherapy was previously considered immunosuppressive because older treatment techniques covered large fields that caused substantial damage to bone marrow and circulating blood [93]. However, it has become clear that radiation can elicit multiple forms of host immune responses affecting the efficacy of radiotherapy [94-96]. Radiotherapy in sarcoma patients induces upregulation of several positive immune effectors, such as NKG2D, CD45, CD3, CD4, CD8, MHC-II, $\beta 2 \mathrm{M}$, perforin, granzyme $\mathrm{B}$, the CT-antigen CT7 and macrophages (CD68, CD163) in a coordinated fashion following radiotherapy, whereas transcripts associated with immune suppression such as IDO, BTLA, FoxP3, PD-L1, IL-10, TGF- $\beta$, STAT-3, CT10, TNF- $\alpha$, and iNOS seem to follow a similar pattern of downregulated expression after radiotherapy [97].

Among these, the immune effector, MHC-I has been the best studied [98-100]. MHC-I presents peptides of 10 to 12 amino acids from a variety of cellular proteins after immunoproteasomal degradation onto the cellular surface via antigen-presenting cells (APC) for the recognition of and activation of $\mathrm{CD}^{+}$cytotoxic T cells (Figure 3 ). MHC-I is normally downregulated in many types of solid tumors for immune-surveillance by the host [101], and $\mathrm{MHC}-1$ downregulation often leads to activation of NK cell killing of target cells [102]. Mechanisms of MHC-I silencing in tumor cells are multifactorial, but one important mechanism is epigenetically regulated including DNA methylation [103, 104] and histone acetylation [105]. $\beta 2$ microglobulin encodes a component of the MHC-I complex. Increasing MHC-I expression by gene delivery of $\beta 2$ microglobulin has been a strategy for increased tumor immunogenicity [106]. $\gamma$-radiation induces MHC-I expression, increase of intracellular peptide pool, antigen presentation, and cytotoxic T lymphocyte recognition of the irradiated cells [98].

Cytotoxic T cells, when activated, produce immunotoxins such as perforin (a pore-forming cytolytic protein allowing passage of proapoptotic proteases), granzymes (a family of serine proteases which activate apoptosis by caspases) and granulin (which is present in cytolytic granules of CTL and NK cells). These cytotoxins enter the cytoplasm of the target cells and elicit cell death mechanisms. Activated T cells are able to homein and infiltrate the tumor; inefficient $\mathrm{T}$ cell migration is a major barrier of cancer immunotherapy. Radiation has been shown to promote these processes [107]. In a B16 murine melanoma model, it was demonstrated that increased production of infiltrating $\mathrm{CD} 45^{+}, \mathrm{CD}^{+} \mathrm{T}$, and tumor-specific $\mathrm{CD}^{+} \mathrm{T}$ cells, and depleting $\mathrm{CD} 8^{+} \mathrm{T}$ cells completely abolished the therapeutic effects [95]. In a preclinical pancreatic tumor model, in which infiltrated $\mathrm{T}$ cells are low, local low-dose irradiation induces recruitment of tumor-specific $\mathrm{T}$ cells through direct radiation effects on the tumor tissues [108]. Another important interaction between radiation and immune system is upregulation of the cell surface death receptor Fas by sublethal irradiation [109]. Fas, by interacting with its ligand FAS-L, induces caspase activation-mediated apoptotic cell death [110]. These findings demonstrate the importance of radiation therapy in cancer immunotherapy and suggest that responses to immunotherapy may be improved by harnessing radiation (Figure 2).

It has been well-established that locoregional irradiation can generate both local and distant effects at sites away from irradiation or the "abscopal effects" [111-114]. The abscopal effects have been attributed to the induced inflammatory cytokines such as IL-1 $\beta$, IL-6, and TNF- $\alpha$ released from the primary tumor site or nontumor cells such as endothelial cells and cancer associated fibroblasts (Figure 3) [115]. These cytokines elicit cellular stress and induce damage-associated molecular pattern (DAMP) molecules which alert the host of danger by triggering the defense system to protect cells from killing effects. High mobility group box 1 (HMGB1), which binds to toll-like receptor on dendritic cells and promotes antigen cross-presentation onto the surface of the T cells, is a well-known DAMP molecule [116] (Figure 1). Another DAMP molecule is calreticulin whose main function is to bind misfolded proteins, preventing them from exposing to the endoplasmic reticulum or Golgi apparatus. Enhanced release of HMGB1 and increased calreticulin expression are important for priming antigenspecific T-cell responses, thereby promoting synergistic effect between radiation and immunotherapy (Figures 2 and 3). Damaged cells induced by irradiation may also increase production of death receptor Fas for killing by tumor antigen-reactive $\mathrm{T}$ cells as mentioned above.

\section{Combined radiotherapy and immunotherapy}

The development of antibody blockade of immune checkpoint regulators such as cytotoxic T-lymphocyteassociated protein 4 (CTLA-4) and the program death-1 and its ligand (PD-1/PD-L1) axis has revolutionized cancer immunotherapy [117]. CTLA-4 is homologous to CD28. The CTLA-4 receptor is located on the surface of effector T lymphocytes and interacts with CD80/CD86 (B7-1 or B7-2) on CTLA-4 antigen-presenting cells to 
induce $\mathrm{T}$ cell rest, preventing overactivation of the $\mathrm{T}$ cell system in autoimmunity [118]. CTLA-4 is up-regulated in response to T-cell activation and induces an inhibitory signal in the T cells. Ipilimumab, a monoclonal antibody against CTLA-4, was approved for treating human melanoma in 2011. Likewise, PD-1, another cell surface receptor, also acts as an inhibitory immune checkpoint. It is expressed on $\mathrm{CD}^{+}$and $\mathrm{CD}^{+} \mathrm{T}$ cells and antigenpresenting cells. The ligands of PD-1 are PD-L1 and PDL2, and anti-bodies against these ligands (atezolizumab and durvalumab) have been developed. When bound to its ligands PD-L1/PD-L2, they elicit a T-cell inhibitory signal through inhibition of T cells costimulastory receptor CD28 but not T cell receptor (TCR) as previously believed [119, 120]. Humanized monoclonal antibodies (penbrolizumab and nivolumab) have been approved for clinical use. Other potential immunoregulatory receptors for immunotherapy under developed are OX40 (CD134) and TIM3 [121].

Preclinical studies have demonstrated that antiPD-1/PD-Li plus radiation induces cytotoxic T lymphocyte activation but suppression of myeloid-derived suppressor cells in a mouse model $[122,123]$. In a murine lung cancer model resistant to $\mathrm{PD}-1$ antibody established by repetitive dosing shows increased expression of the antigen presentation pathway, including MHC-I and MHC-II, and reduced $\mathrm{CD}^{+}, \mathrm{CD}^{+}$lymphocytes and infiltrating lymphocytes. Local tumor radiation in this model induces IFN $\beta$ and MHC-I production and resensitization to anti-PD-1 antibody therapy. These results suggest that radiotherapy can overcome $\mathrm{PD}-1$ resistance via upregulation of the MHC system [124]. These preclinical results showed that radiation and immune checkpoint blockade possess promise for synergistic effects.

A synergistic effect of immunotherapy combined with radiotherapy is the abscopal effect. This has been reported in melanoma patients and lung patients using radiotherapy in combination with ipilimumab [113]. Lung cancer patients treated with radiotherapy and ipilimumab increases tumor-infiltrating cytotoxic lymphocytes which cause tumor regression [125]. In a phase I trial using stereotactic ablative radiation therapy with ipilimumab involving 32 patients, it was demonstrated that clinical benefit was associated with increased peripheral CD8+ T-cells, CD8+/CD4+ T-cell ratio, and proportion of $\mathrm{CD}^{+}$ T-cells expressing 4-1BB and PD1 [126]. In another study using local radiotherapy combined with systemic ipilimumab immunotherapy in 22 patients with stage IV melanoma showed that $50 \%$ of the treated patients benefited from the treatment, and response was correlated with elevated CD8-activated T-cells, suggesting abscopal effects from the treatment. Further improvement in the treatment effects was observed in radiation plus dual immune checkpoint blockade (anti-CTLA-4 and antiPD-L1), suggesting non-redundant mechanisms in this triple treatment scheme. It was revealed that CTLA-4 blockade primarily decreases Treg cells, PD-L1 blockade

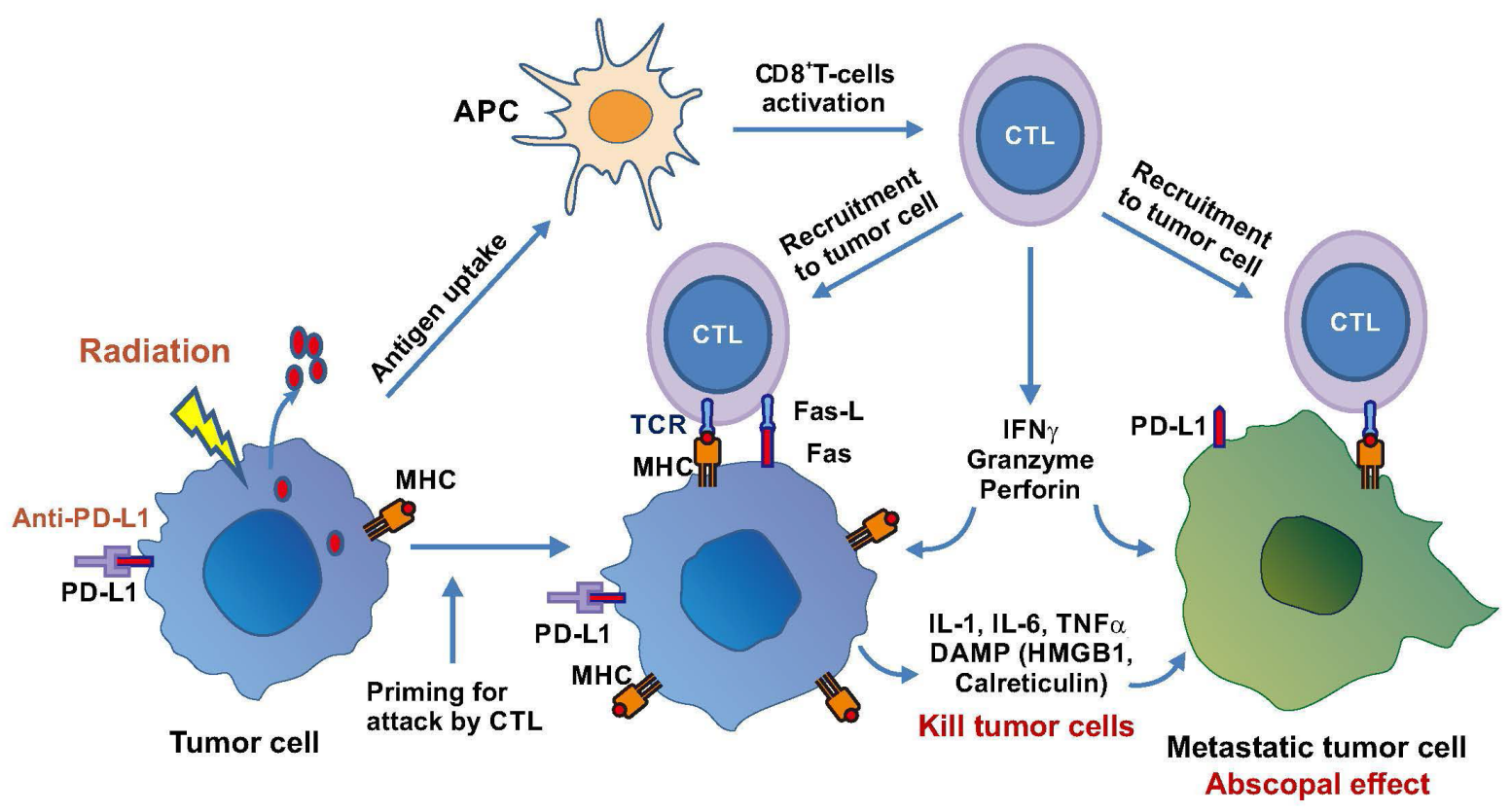

Figure 3: Radiation-induced immune response in cancer therapy. Radiation induces release of tumor antigens which are captured and processed by antigen-presenting cells (APC) to activate cytotoxic T lymphocytes (CTL). CTL are recruited to attack tumor cells or metastatic cells to elicit abscopal effect. Radiation also upregulates PD-L1 and combination with anti-PD-L1 therapy enhances MHC and Fas expression on tumor cells and increases T-cell-mediated cytotoxicity including releases of cytokines and DAMP to elicit killing of primary and metastatic tumor cells. 
predominantly reinvigorates exhausted $\mathrm{CD} 8^{+} \mathrm{TILs}$, and radiation diversifies the TCR repertoire of TILs from unirradiated tumors [127].

Preclinical studies have demonstrated that dose and schedule of radiotherapy are important in eliciting anti-tumor activities, and this is the case with immune checkpoint inhibition as well. In general, hypofractionated radiotherapy has been found to be more effective than single high-dose radiotherapy in generating anti-tumor immune response with anti-CTLA-4 [128]. Fractionated radiotherapy in combination with ipilimumab have been used in clinical studies [129-131]. Results from these studies suggested that subsets of patients have more favorable responses. These findings encourage further investigations using radiation and immunotherapy in cancer treatment.

Currently, there are about 20 active clinical trials combining radiation with CTLA-4 inhibition and more than 50 trials combining radiation with PD-1/PD-L1 therapy in a wide range of malignancies [96]. Metastatic melanoma is the most common indication in these trials. While the results of these ongoing trials are not yet available, this enthusiasm should generate ample information for designing optimal dosing and sequencing of radiation treatments. The results may also provide new biomarkers for optimizing treatment sensitivity while minimizing overlapping toxic effects of radiation and immunotherapy.

\section{Personalized radiation-immunotherapy, is it feasible?}

An important hallmark of cancer is genomic instability, which is the fundamental mechanism for the generation of neoantigens. Neoantigens are processed and presented on the surface of neoplastic cells by the pathways of MHC systems and recognized by $\mathrm{CD} 8^{+}$ TCR. It has been demonstrated that patients with genomic instability traits fare better with immunotherapy using PD-1 [132] and CTLA-4 blockade [133, 134]. Consistent with these findings, a recent report showed that melanoma patients with high mutation loads as determined by NGS responded better to anti-PD1/PD-L1 therapy [135]. Thus, neoantigen load may be considered a biomarker in cancer immunotherapy $[117,136]$. Radiation damage would produce large amount of tumor neoantigens for presentation by antigen-presenting cells. Moreover, such damage would activate inflammatory signals to induce antigen-presenting maturation and migration to activate naïve T cells [137].

Neoantigens raised from non-synonymous mutations of tumor DNA [117, 138], generating mutated peptides that are presented by the MHC system to induce CD4 and CD8 T cells responses. Recent studies have demonstrated correlations between abundance of tumor neoantigens (or neoantigen load) and microsatellite-instability status in colorectal cancers [139] and endometrial cancer [140]. Strikingly, a stronger association between clinical response and mismatch repair deficiency than that with mismatch repair proficient tumors to PD-1 blockade was found in advanced urothelial carcinoma [141]. Additionally, melanoma bearing high-mutation loads showed improved overall survival with anti-PD1, and tumors from responding patients are enriched in mutations in the DNA repair gene BRCA2 [142].

The size of the neoantigen repertoire with $\mathrm{T}$ cell reactivity is not known. However, with the advancement of deep-sequencing and mass spectrometry technology, more and more patient-specific neoantigens are beginning to unravel. Recently, Riaz et al have found two neoantigens, SERPIN3 and SERPINB4, the human ovalbumin antigen, which are associated with autoimmunity, are also correlated with improved survival after anti-CTLA-4 immunotherapy in patients with melanoma [143].

Neoantigens derived from tumor-specific lymphocytes have been identified in the circulating bloods of melanoma patients. It was previously demonstrated that tumor-infiltrating $\mathrm{T}$ cells in human melanoma are enriched in $\mathrm{PD}-1^{+}$subpopulation [144]. Because the scarcity of the cell source, the authors first isolated a $\mathrm{CD} 8^{+}$ PD- $1^{+}$population from patients using flow cytometry. Neoantigens were determined by deep-DNA sequencing of patients' tumor specimens. These observations have important implications for providing a noninvasive and simplified strategy for producing of patients specific TIL for immunotherapy.

These observations suggest that exposures to mutagens such as ultraviolet light in melanoma and tobacco smoking [145] in NSCLC may increase mutational loads leading to increased immunogenic neoantigens production. Indeed, these have been found in clinical data [146-148]. In a recent study involving whole exome sequencing of 16 pairs of matched specimens of squamous cell carcinoma of anal canal cancer from patients before and after recurrent disease treated with concurrent chemotherapy and radiotherapy, while overall mutational spectra were not significantly different between pre- and post-treatment tumors, one patient with recurrent disease was exceptional response to anti-PD-1 therapy. High mutational burden and predicted neoantigen load were observed in the tumors [149]. More studies are needed to better understand mutational dynamics and neoantigen presentation in response to radiationimmunotherapy. These studies may lead to successful personalized radiotherapy in the future.

\section{CONCLUSIONS AND FUTURE PERSPECTIVES}

Two major driving forces have come together that improved the treatment efficacy of radiotherapy in recent 
years. One is the advancement of technology of dose conformity such as IMRT, SBRT, and IGRT, allowing more precise delivery of high-dose radiation to the target volume with reduced injury on healthy tissues. And the other is a better understanding of radiosensitivity/ resistance mechanisms at the molecular and cellular levels which enable the development of radiosensitizers and radioprotectors. Radiotherapy was traditionally used in combination with chemotherapy or surgery in treating human malignancies. Taking advantage of successful checkpoint blockade immunotherapy in multiple tumor types, radiation-immunotherapy has become an area of intensive ongoing investigations and the overall results will soon be available.

As we move into the era of personalized medicine, the future of radiotherapy decision-making will continue to evolve by integrating information based on individual patient's DNA data, gene and proteomic expression profilings, tumor metabolomes, and immunology. Combining traditional mechanism-based radiation oncology with new knowledge derived from these new developments will continue to improve the treatment efficacy using multiple treatment modalities and radiotherapy will continue to play an important part in these modalities.

While locoregional tumors can be effectively treated by radiotherapy, metastatic cancers are difficult to treat and representing an important challenge in radiotherapy. Effective abscopal response in radiotherapy is critical to combating widespread metastatic disease. While therapeutic efficacy has often emphasized the overall survival and progression-free rates, radiation-induced toxicity in the normal tissues cannot be neglected. Radiation can induce adverse effects such as fibrosis in normal tissues and immune toxicity such as exacerbation of autoimmunity and inflammation, resulting in pulmonary pneumonitis when combined with immunotherapy. Both can affect quality of life and may even lead to death. Thus, the traditional concept of a "therapeutic window", which refers to the dose range that provides maximal effective therapy without harmfully affect normal tissue, is of great importance. Like many other forms of cancer therapy, radiotherapy must constantly strive to widen the therapeutic window to improve overall treatment efficacy. Uncovering and effectively utilizing new knowledge from multiple disciplines to optimize radiotherapy is critical to this endeavor. Although much work remains to be done, new information continues to pour-in that can benefit radiation research. The future for radiation therapy looks bright.

\section{ACKNOWLEDGMENTS}

We thank Ms. Sarah Bronson, ELS, (Department of Scientific Publications, The University of Texas MD Anderson Cancer Center) for editorial assistance. This work was supported in part by grants from the Ministry of Science and Technology, Taiwan (MOST-105-2314-B006-046-My3 to HHWC) and from the National Cancer institute, USA (1RO1 CA149260 to MTK and Cancer Support Grant P30 CA16672 to MD Anderson Cancer Center).

\section{CONFLICTS OF INTEREST}

The authors have no conflicts of interest.

\section{REFERENCES}

1. Baumann M, Krause M, Overgaard J, Debus J, Bentzen SM, Daartz J, Richter C, Zips D, Bortfeld T. Radiation oncology in the era of precision medicine. Nature Rev Cancer. 2016; 16:234-249.

2. Le QT, Shirato H, Giaccia AJ, Koong AC. Emerging Treatment Paradigms in Radiation Oncology. Clin Cancer Res. 2015; 21:3393-3401.

3. Morrison R, Schleicher SM, Sun Y, Niermann KJ, Kim S, Spratt DE, Chung CH, Lu B. Targeting the mechanisms of resistance to chemotherapy and radiotherapy with the cancer stem cell hypothesis. J Oncol. 2011; 2011:941876.

4. Dolgin E. Using DNA, radiation therapy gets personal. Science. 2016; 353:1348-1349.

5. Druker BJ, Lydon NB. Lessons learned from the development of an abl tyrosine kinase inhibitor for chronic myelogenous leukemia. J Clin Inv. 2000; 105:3-7.

6. Bollag G, Tsai J, Zhang J, Zhang C, Ibrahim P, Nolop K, Hirth P. Vemurafenib: the first drug approved for BRAFmutant cancer. Nat Rev Drug Discov. 2012; 11:873-886.

7. Frey B, Rubner Y, Kulzer L, Werthmoller N, Weiss EM, Fietkau R, Gaipl US. Antitumor immune responses induced by ionizing irradiation and further immune stimulation. Cancer Immunol Immunother: CII. 2014; 63:29-36.

8. Milas L, Fan Z, Andratschke NH, Ang KK. Epidermal growth factor receptor and tumor response to radiation: in vivo preclinical studies. Intern J Radiat Oncol, biol, Phys. 2004; 58:966-971.

9. Kriegs M, Gurtner K, Can Y, Brammer I, Rieckmann T, Oertel R, Wysocki M, Dorniok F, Gal A, Grob TJ, Laban S, Kasten-Pisula U, Petersen C, et al. Radiosensitization of NSCLC cells by EGFR inhibition is the result of an enhanced p53-dependent G1 arrest. Radiotherapy and oncology: J Eur Soc Therapeut Radiol Oncol. 2015; 115:120-127.

10. Ang KK, Zhang Q, Rosenthal DI, Nguyen-Tan PF, Sherman EJ, Weber RS, Galvin JM, Bonner JA, Harris J, El-Naggar AK, Gillison ML, Jordan RC, Konski AA, et al. Randomized phase III trial of concurrent accelerated radiation plus cisplatin with or without cetuximab for stage III to IV head and neck carcinoma: RTOG 0522. J Clin Oncol. 2014; 32:2940-2950. 
11. Crosby T, Hurt CN, Falk S, Gollins S, Mukherjee S, Staffurth J, Ray R, Bashir N, Bridgewater JA, Geh JI, Cunningham D, Blazeby J, Roy R, et al. Chemoradiotherapy with or without cetuximab in patients with oesophageal cancer (SCOPE1): a multicentre, phase 2/3 randomised trial. Lancet Oncology. 2013; 14:627-637.

12. Azzam EI, Jay-Gerin JP, Pain D. Ionizing radiation-induced metabolic oxidative stress and prolonged cell injury. Cancer Lett. 2012; 327:48-60.

13. Yamamori T, Yasui H, Yamazumi M, Wada Y, Nakamura Y, Nakamura H, Inanami O. Ionizing radiation induces mitochondrial reactive oxygen species production accompanied by upregulation of mitochondrial electron transport chain function and mitochondrial content under control of the cell cycle checkpoint. Free Radical Biology Med. 2012; 53:260-270.

14. Richardson RB, Harper ME. Mitochondrial stress controls the radiosensitivity of the oxygen effect: Implications for radiotherapy. Oncotarget. 2016; 7:21469-21483. doi: 10.18632/oncotarget.7412.

15. Tateishi Y, Sasabe E, Ueta E, Yamamoto T. Ionizing irradiation induces apoptotic damage of salivary gland acinar cells via NADPH oxidase 1-dependent superoxide generation. Biochem Biophys Res Comm. 2008; 366:301-307.

16. Wang C, Pan Z, Hou H, Li D, Mo Y, Mo C, Li J. The Enhancement of Radiation Sensitivity in Nasopharyngeal Carcinoma Cells via Activation of the Rac1/NADPH Signaling Pathway. Radiation Res. 2016; 185:638-646.

17. Zhang Y, Martin SG. Redox proteins and radiotherapy. Clin Oncol. 2014; 26:289-300.

18. Jeong Y, Hoang NT, Lovejoy A, Stehr H, Newman AM, Gentles AJ, Kong W, Truong D, Martin S, Chaudhuri A, Heiser D, Zhou L, Say C, et al. Role of KEAP1/NRF2 and TP53 Mutations in Lung Squamous Cell Carcinoma Development and Radiation Resistance. Cancer Discov. 2017; 7:86-101.

19. Woolston CM, Storr SJ, Ellis IO, Morgan DA, Martin SG. Expression of thioredoxin system and related peroxiredoxin proteins is associated with clinical outcome in radiotherapy treated early stage breast cancer. Radiother Oncol. 2011; 100:308-313.

20. Bhardwaj R, Sharma PK, Jadon SP, Varshney R. A combination of 2-deoxy-D-glucose and 6-aminonicotinamide induces cell cycle arrest and apoptosis selectively in irradiated human malignant cells. Tumour Biol. 2012; 33:1021-1030.

21. Verma V. Relationship and interactions of curcumin with radiation therapy. World J Clin Oncol. 2016; 7:275-283.

22. Sun Y, St Clair DK, Xu Y, Crooks PA, St Clair WH. A NADPH oxidase-dependent redox signaling pathway mediates the selective radiosensitization effect of parthenolide in prostate cancer cells. Cancer Res. 2010; 70:2880-2890.

23. Trpkov K, Hes O, Agaimy A, Bonert M, Martinek P, MagiGalluzzi C, Kristiansen G, Luders C, Nesi G, Comperat E, Sibony M, Berney DM, Mehra R, et al. Fumarate Hydratase-deficient Renal Cell Carcinoma Is Strongly Correlated With Fumarate Hydratase Mutation and Hereditary Leiomyomatosis and Renal Cell Carcinoma Syndrome. Am J Surg Pathol. 2016; 40:865-875.

24. Sullivan LB, Martinez-Garcia E, Nguyen H, Mullen AR, Dufour E, Sudarshan S, Licht JD, Deberardinis RJ, Chandel NS. The proto-oncometabolite fumarate binds glutathione to amplify ROS-dependent signaling. Molec Cell. 2013; 51:236-248.

25. Zheng L, Cardaci S, Jerby L, MacKenzie ED, Sciacovelli M, Johnson TI, Gaude E, King A, Leach JD, Edrada-Ebel R, Hedley A, Morrice NA, Kalna G, et al. Fumarate induces redox-dependent senescence by modifying glutathione metabolism. Nature Commu. 2015; 6:6001.

26. Boivin A, Hanot M, Malesys C, Maalouf M, Rousson R, Rodriguez-Lafrasse C, Ardail D. Transient alteration of cellular redox buffering before irradiation triggers apoptosis in head and neck carcinoma stem and non-stem cells. PloS one. 2011; 6:e14558.

27. Held KD, Epp ER, Clark EP, Biaglow JE. Effect of dimethyl fumarate on the radiation sensitivity of mammalian cells in vitro. Radiation Res. 1988; 115:495-502.

28. Pham D, Thompson A, Kron T, Foroudi F, Kolsky MS, Devereux T, Lim A, Siva S. Stereotactic ablative body radiation therapy for primary kidney cancer: a 3-dimensional conformal technique associated with low rates of early toxicity. Internat J Radiat Oncol, Biol, Physics. 2014; 90:1061-1068.

29. Zelefsky MJ, Greco C, Motzer R, Magsanoc JM, Pei X, Lovelock M, Mechalakos J, Zatcky J, Fuks Z, Yamada Y. Tumor control outcomes after hypofractionated and single-dose stereotactic image-guided intensity-modulated radiotherapy for extracranial metastases from renal cell carcinoma. Internat J Radiat Oncol, Biol, Phys. 2012; 82:1744-1748.

30. Brizel DM, Wasserman TH, Henke M, Strnad V, Rudat V, Monnier A, Eschwege F, Zhang J, Russell L, Oster W, Sauer R. Phase III randomized trial of amifostine as a radioprotector in head and neck cancer. J Clin Oncol 2000; 18:3339-3345.

31. Hofer M, Falk M, Komurkova D, Falkova I, Bacikova A, Klejdus B, Pagacova E, Stefancikova L, Weiterova L, Angelis KJ, Kozubek S, Dusek L, Galbavy S. Two New Faces of Amifostine: Protector from DNA Damage in Normal Cells and Inhibitor of DNA Repair in Cancer Cells. J Med Chem. 2016; 59:3003-3017. 
32. Todoric J, Antonucci L, Karin M. Targeting Inflammation in Cancer Prevention and Therapy. Cancer Prev Res. 2016; 9:895-905.

33. Lamkanfi M, Dixit VM. Mechanisms and functions of inflammasomes. Cell. 2014; 157:1013-1022.

34. Strowig T, Henao-Mejia J, Elinav E, Flavell R. Inflammasomes in health and disease. Nature. 2012; 481:278-286.

35. Dubois H, Wullaert A, Lamkanfi M. General Strategies in Inflammasome Biology. Current Top Microbiol Immunol. 2016; 397:1-22.

36. Sohn SH, Lee JM, Park S, Yoo H, Kang JW, Shin D, Jung $\mathrm{KH}$, Lee YS, Cho J, Bae H. The inflammasome accelerates radiation-induced lung inflammation and fibrosis in mice. Environ Toxicol Pharmacol. 2015; 39:917-926.

37. Licandro G, Ling Khor H, Beretta O, Lai J, Derks H, Laudisi F, Conforti-Andreoni C, Liang Qian H, Teng GG, Ricciardi-Castagnoli P, Mortellaro A. The NLRP3 inflammasome affects DNA damage responses after oxidative and genotoxic stress in dendritic cells. Europ J Immunol. 2013; 43:2126-2137.

38. Fernandes-Alnemri T, Yu JW, Datta P, Wu J, Alnemri ES. AIM2 activates the inflammasome and cell death in response to cytoplasmic DNA. Nature. 2009; 458:509-513.

39. Hornung V, Ablasser A, Charrel-Dennis M, Bauernfeind F, Horvath G, Caffrey DR, Latz E, Fitzgerald KA. AIM2 recognizes cytosolic dsDNA and forms a caspase-1activating inflammasome with ASC. Nature. 2009; 458:514-518.

40. Dansen TB, Smits LM, van Triest MH, de Keizer PL, van Leenen D, Koerkamp MG, Szypowska A, Meppelink A, Brenkman AB, Yodoi J, Holstege FC, Burgering BM. Redox-sensitive cysteines bridge p300/CBP-mediated acetylation and FoxO4 activity. Nature Chem Biol. 2009; 5:664-672.

41. Mladenov E, Magin S, Soni A, Iliakis G. DNA double-strand break repair as determinant of cellular radiosensitivity to killing and target in radiation therapy. Frontiers Oncol. 2013; 3:113.

42. O'Connor MJ. Targeting the DNA Damage Response in Cancer. Mol Cell. 2015; 60:547-560.

43. Morgan MA, Lawrence TS. Molecular Pathways: Overcoming Radiation Resistance by Targeting DNA Damage Response Pathways. Clin Cancer Res. 2015; 21:2898-2904.

44. Kan C, Zhang J. BRCA1 Mutation: A Predictive Marker for Radiation Therapy? Internat Radiat Oncol, Biol, Physics. 2015; 93:281-293.

45. Meehan RS, Chen AP. New treatment option for ovarian cancer: PARP inhibitors. Gynecol Oncol Res Pract. 2016; $3: 3$.

46. Lin KY, Kraus WL. PARP Inhibitors for Cancer Therapy. Cell. 2017; 169:183.
47. Pitroda SP, Pashtan IM, Logan HL, Budke B, Darga TE, Weichselbaum RR, Connell PP. DNA repair pathway gene expression score correlates with repair proficiency and tumor sensitivity to chemotherapy. Sci Transl Med. 2014; 6:229ra242.

48. Kinzel L, Ernst A, Orth M, Albrecht V, Hennel R, Brix N, Frey B, Gaipl US, Zuchtriegel G, Reichel CA, Blutke A, Schilling D, Multhoff G, et al. A novel HSP90 inhibitor with reduced hepatotoxicity synergizes with radiotherapy to induce apoptosis, abrogate clonogenic survival, and improve tumor control in models of colorectal cancer. Oncotarget. 2016; 7:43199-43219. doi: 10.18632/ oncotarget.9774.

49. Wang Y, Liu H, Diao L, Potter A, Zhang J, Qiao Y, Wang J, Proia DA, Tailor R, Komaki R, Lin SH. Hsp90 Inhibitor Ganetespib Sensitizes Non-Small Cell Lung Cancer to Radiation but Has Variable Effects with Chemoradiation. Clin Cancer Res. 2016; 22:587605886.

50. Ernst A, Anders H, Kapfhammer H, Orth M, Hennel R, Seidl K, Winssinger N, Belka C, Unkel S, Lauber K. HSP90 inhibition as a means of radiosensitizing resistant, aggressive soft tissue sarcomas. Cancer Lett. 2015; 365:211-222.

51. Proia DA, Bates RC. Ganetespib and HSP90: translating preclinical hypotheses into clinical promise. Cancer Res. 2014; 74:1294-1300.

52. Fyles A, Milosevic M, Hedley D, Pintilie M, Levin W, Manchul L, Hill RP. Tumor hypoxia has independent predictor impact only in patients with node-negative cervix cancer. J Clin Oncol. 2002; 20:680-687.

53. Nordsmark M, Bentzen SM, Rudat V, Brizel D, Lartigau E, Stadler P, Becker A, Adam M, Molls M, Dunst J, Terris DJ, Overgaard J. Prognostic value of tumor oxygenation in 397 head and neck tumors after primary radiation therapy. An international multi-center study. Radiother Oncol. 2005; 77:18-24.

54. Nordsmark M, Alsner J, Keller J, Nielsen OS, Jensen OM, Horsman MR, Overgaard J. Hypoxia in human soft tissue sarcomas: adverse impact on survival and no association with p53 mutations. British J Cancer. 2001; 84:1070-1075.

55. Wilson WR, Hay MP. Targeting hypoxia in cancer therapy. Nature Rev Cancer. 2011; 11:393-410.

56. Brizel DM, Dodge RK, Clough RW, Dewhirst MW. Oxygenation of head and neck cancer: changes during radiotherapy and impact on treatment outcome. Radiother Oncol. 1999; 53:113-117.

57. Thomson D, Yang H, Baines H, Miles E, Bolton S, West C, Slevin N. NIMRAD - a phase III trial to investigate the use of nimorazole hypoxia modification with intensitymodulated radiotherapy in head and neck cancer. Clin Oncol. 2014; 26:344-347.

58. Overgaard J. Hypoxic modification of radiotherapy in squamous cell carcinoma of the head and neck--a 
systematic review and meta-analysis. Radiother Oncol. 2011; 100:22-32.

59. Das S, Dubey R, Roychowdhury S, Ghosh M, Sinha BN, Kumar Pradhan K, Bal T, Muthukrishnan V, Seijas JA, Pujarid A. A rapid and sensitive determination of hypoxic radiosensitizer agent nimorazole in rat plasma by LC-MS/ MS and its application to a pharmacokinetic study. Biomedical chromatography: BMC. 2015; 29:1575-1580.

60. Overgaard J, Hansen HS, Overgaard M, Bastholt L, Berthelsen A, Specht L, Lindelov B, Jorgensen K. A randomized double-blind phase III study of nimorazole as a hypoxic radiosensitizer of primary radiotherapy in supraglottic larynx and pharynx carcinoma. Results of the Danish Head and Neck Cancer Study (DAHANCA) Protocol 5-85. Radiother Oncol. 1998; 46:135-146.

61. Ang KK. More lessons learned from the suffocation of hypoxia. J Clin Oncol. 2010; 28:2941-2943.

62. Bentzen J, Toustrup K, Eriksen JG, Primdahl H, Andersen LJ, Overgaard J. Locally advanced head and neck cancer treated with accelerated radiotherapy, the hypoxic modifier nimorazole and weekly cisplatin. Results from the DAHANCA 18 phase II study. Acta oncologica. 2015; 54:1001-1007.

63. Dorie MJ, Brown JM. Tumor-specific, schedule-dependent interaction between tirapazamine (SR 4233) and cisplatin. Cancer Res. 1993; 53:4633-4636.

64. Rischin D, Peters LJ, O'Sullivan B, Giralt J, Fisher R, Yuen K, Trotti A, Bernier J, Bourhis J, Ringash J, Henke M, Kenny L. Tirapazamine, cisplatin, and radiation versus cisplatin and radiation for advanced squamous cell carcinoma of the head and neck (TROG 02.02, HeadSTART): a phase III trial of the TransTasman Radiation Oncology Group. J Clin Oncol. 2010; 28:2989-2995.

65. Chau NG, Li YY, Jo VY, Rabinowits G, Lorch JH, Tishler RB, Margalit DN, Schoenfeld JD, Annino DJ, Goguen LA, Thomas T, Becker H, Haddad T, et al. Incorporation of Next-Generation Sequencing into Routine Clinical Care to Direct Treatment of Head and Neck Squamous Cell Carcinoma. Clin Cancer Res. 2016; 22:2939-2949.

66. Morris LG, Chandramohan R, West L, Zehir A, Chakravarty D, Pfister DG, Wong RJ, Lee NY, Sherman EJ, Baxi SS, Ganly I, Singh B, Shah JP, et al. The Molecular Landscape of Recurrent and Metastatic Head and Neck Cancers: Insights From a Precision Oncology Sequencing Platform. JAMA Oncol. 2016 (in press). doi: 10.1001/ jamaoncol.2016.1790.

67. Michailidou K, Beesley J, Lindstrom S, Canisius S, Dennis J, Lush MJ, Maranian MJ, Bolla MK, Wang Q, Shah M, Perkins BJ, Czene K, Eriksson M, et al. Genome-wide association analysis of more than 120,000 individuals identifies 15 new susceptibility loci for breast cancer. Nature Genet. 2015; 47:373-380.
68. Dorling L, Barnett GC, Michailidou K, Coles CE, Burnet NG, Yarnold J, Elliott RM, Dunning AM, Pharoah PD, West CM. Patients with a High Polygenic Risk of Breast Cancer do not have An Increased Risk of Radiotherapy Toxicity. Clin Cancer Res. 2016; 22:1413-1420.

69. Hummerich J, Werle-Schneider G, Popanda O, Celebi O, Chang-Claude J, Kropp S, Mayer C, Debus J, Bartsch $\mathrm{H}$, Schmezer P. Constitutive mRNA expression of DNA repair-related genes as a biomarker for clinical radioresistance: A pilot study in prostate cancer patients receiving radiotherapy. Interna J Radiation Biol. 2006; 82:593-604.

70. Eschrich SA, Fulp WJ, Pawitan Y, Foekens JA, Smid M, Martens JW, Echevarria M, Kamath V, Lee JH, Harris EE, Bergh J, Torres-Roca JF. Validation of a radiosensitivity molecular signature in breast cancer. Clinical Cancer Res. 2012; 18:5134-5143.

71. Zhao SG, Chang SL, Spratt DE, Erho N, Yu M, Ashab HA, Alshalalfa M, Speers C, Tomlins SA, Davicioni E, Dicker AP, Carroll PR, Cooperberg MR, et al. Development and validation of a 24-gene predictor of response to postoperative radiotherapy in prostate cancer: a matched, retrospective analysis. Lancet Oncol. 2016; 17:1612-1620.

72. Ahmed KA, Chinnaiyan P, Fulp WJ, Eschrich S, TorresRoca JF, Caudell JJ. The radiosensitivity index predicts for overall survival in glioblastoma. Oncotarget. 2015; 6:34414-34422. doi: 10.18632/oncotarget.5437.

73. Peitzsch C, Cojoc M, Hein L, Kurth I, Mabert K, Trautmann F, Klink B, Schrock E, Wirth MP, Krause M, Stakhovsky EA, Telegeev GD, Novotny V, et al. An Epigenetic Reprogramming Strategy to Resensitize Radioresistant Prostate Cancer Cells. Cancer Res. 2016; 76:2637-2651.

74. Weigel C, Schmezer P, Plass C, Popanda O. Epigenetics in radiation-induced fibrosis. Oncogene. 2015; 34:2145-2155.

75. Yarnold J, Brotons MC. Pathogenetic mechanisms in radiation fibrosis. Radiother and Oncol. 2010; 97:149-161.

76. Straub JM, New J, Hamilton CD, Lominska C, Shnayder Y, Thomas SM. Radiation-induced fibrosis: mechanisms and implications for therapy. J Cancer Res and Clin Oncol. 2015; 141:1985-1994.

77. Forrester HB, Li J, Leong T, McKay MJ, Sprung CN. Identification of a radiation sensitivity gene expression profile in primary fibroblasts derived from patients who developed radiotherapy-induced fibrosis. Radiothera Oncol. 2014; 111:186-193.

78. Koerdt S, Rohleder NH, Rommel N, Nobis C, Stoeckelhuber M, Pigorsch S, Duma MN, Wolff KD, Kesting MR. An expression analysis of markers of radiation-induced skin fibrosis and angiogenesis in wound healing disorders of the head and neck. Radiation Oncol. 2015; 10:202.

79. Svensson JP, Stalpers LJ, Esveldt-van Lange RE, Franken NA, Haveman J, Klein B, Turesson I, Vrieling H, 
Giphart-Gassler M. Analysis of gene expression using gene sets discriminates cancer patients with and without late radiation toxicity. PLoS medicine. 2006; 3:e422.

80. Mayer C, Popanda O, Greve B, Fritz E, Illig T, EckardtSchupp F, Gomolka M, Benner A, Schmezer P. A radiationinduced gene expression signature as a tool to predict acute radiotherapy-induced adverse side effects. Cancer Lett. 2011; 302:20-28.

81. Landmark-Hoyvik H, Dumeaux V, Reinertsen KV, Edvardsen H, Fossa SD, Borresen-Dale AL. Blood gene expression profiling of breast cancer survivors experiencing fibrosis. Internat J Radiat Oncol, Biol, Physics. 2011; 79:875-883.

82. Flechsig P, Dadrich M, Bickelhaupt S, Jenne J, Hauser K, Timke C, Peschke P, Hahn EW, Grone HJ, Yingling J, Lahn M, Wirkner U, Huber PE. LY2109761 attenuates radiationinduced pulmonary murine fibrosis via reversal of TGF-beta and BMP-associated proinflammatory and proangiogenic signals. Clin Cancer Res. 2012; 18:3616-3627.

83. Jacobson G, Bhatia S, Smith BJ, Button AM, Bodeker K, Buatti J. Randomized trial of pentoxifylline and vitamin E vs standard follow-up after breast irradiation to prevent breast fibrosis, evaluated by tissue compliance meter. Internat J Radiat Oncol, Biol, Phys. 2013; 85:604-608.

84. Miyamoto DT, Sequist LV, Lee RJ. Circulating tumour cells-monitoring treatment response in prostate cancer. Nature Rew Clin Oncol. 2014; 11:401-412.

85. Martin OA, Anderson RL, Russell PA, Cox RA, Ivashkevich A, Swierczak A, Doherty JP, Jacobs DH, Smith J, Siva S, Daly PE, Ball DL, Martin RF, MacManus MP. Mobilization of viable tumor cells into the circulation during radiation therapy. Internat J RAdiation Oncol, Biol, Physics. 2014; 88:395-403.

86. Su PJ, Wu MH, Wang HM, Lee CL, Huang WK, Wu CE, Chang HK, Chao YK, Tseng CK, Chiu TK, Lin NM, Ye SR, Lee JY, Hsieh CH. Circulating Tumour Cells as an Independent Prognostic Factor in Patients with Advanced Oesophageal Squamous Cell Carcinoma Undergoing Chemoradiotherapy. Scientific Rep. 2016; 6:31423.

87. Rack B, Schindlbeck C, Juckstock J, Andergassen U, Hepp P, Zwingers T, Friedl TW, Lorenz R, Tesch H, Fasching PA, Fehm T, Schneeweiss A, Lichtenegger W, et al. Circulating tumor cells predict survival in early average-to-high risk breast cancer patients. J Nat Cancer Institut. 2014; 106. doi: 10.1093/jnci/dju066.

88. Saunders M, Dische S, Barrett A, Harvey A, Griffiths G, Palmar M. Continuous, hyperfractionated, accelerated radiotherapy (CHART) versus conventional radiotherapy in non-small cell lung cancer: mature data from the randomised multicentre trial. CHART Steering committee. Radiother Oncol. 1999; 52:137-148.

89. Lannering B, Rutkowski S, Doz F, Pizer B, Gustafsson G, Navajas A, Massimino M, Reddingius R, Benesch M, Carrie C, Taylor R, Gandola L, Bjork-Eriksson
$\mathrm{T}$, et al. Hyperfractionated versus conventional radiotherapy followed by chemotherapy in standard-risk medulloblastoma: results from the randomized multicenter HIT-SIOP PNET 4 trial. J Clin Oncol. 2012; 30:3187-3193.

90. Kim MY, Oskarsson T, Acharyya S, Nguyen DX, Zhang $\mathrm{XH}$, Norton L, Massague J. Tumor self-seeding by circulating cancer cells. Cell. 2009; 139:1315-1326.

91. Vilalta M, Rafat M, Giaccia AJ, Graves EE. Recruitment of circulating breast cancer cells is stimulated by radiotherapy. Cell Rep. 2014; 8:402-409.

92. Early Breast Cancer Trialists' Collaborative G, Darby S, McGale P, Correa C, Taylor C, Arriagada R, Clarke M, Cutter D, Davies C, Ewertz M, Godwin J, Gray R, Pierce L, et al. Effect of radiotherapy after breast-conserving surgery on 10-year recurrence and 15-year breast cancer death: meta-analysis of individual patient data for 10,801 women in 17 randomised trials. Lancet. 2011; 378:1707-1716.

93. Order SE. The effects of therapeutic irradiation on lymphocytes and immunity. Cancer. 1977; 39:737-743.

94. Sharabi AB, Lim M, DeWeese TL, Drake CG. Radiation and checkpoint blockade immunotherapy: radiosensitisation and potential mechanisms of synergy. Lancet Oncol. 2015; 16:e498-509.

95. Surace L, Scheifinger NA, Gupta A, van den Broek M. Radiotherapy supports tumor-specific immunity by acute inflammation. Oncoimmunology. 2016; 5:e1060391.

96. Kang J, Demaria S, Formenti S. Current clinical trials testing the combination of immunotherapy with radiotherapy. J Immunothera Cancer. 2016; 4:51.

97. Sharma A, Bode B, Studer G, Moch H, Okoniewski M, Knuth A, von Boehmer L, van den Broek M. Radiotherapy of human sarcoma promotes an intratumoral immune effector signature. Clin Cancer Res. 2013; 19:4843-4853.

98. Reits EA, Hodge JW, Herberts CA, Groothuis TA, Chakraborty M, Wansley EK, Camphausen K, Luiten $\mathrm{RM}$, de $\mathrm{Ru} \mathrm{AH}$, Neijssen J, Griekspoor A, Mesman E, Verreck FA, et al. Radiation modulates the peptide repertoire, enhances MHC class I expression, and induces successful antitumor immunotherapy. J Exp Med. 2006; 203:1259-1271.

99. Wan S, Pestka S, Jubin RG, Lyu YL, Tsai YC, Liu LF. Chemotherapeutics and radiation stimulate MHC class I expression through elevated interferon-beta signaling in breast cancer cells. PloS one. 2012; 7:e32542.

100. Hauser SH, Calorini L, Wazer DE, Gattoni-Celli S. Radiation-enhanced expression of major histocompatibility complex class I antigen $\mathrm{H}-2 \mathrm{Db}$ in B16 melanoma cells. Cancer Res. 1993; 53:1952-1955.

101. Reeves E, James E. Antigen processing and immune regulation in the response to tumours. Immunology. 2016.

102. Carrillo-Bustamante P, Kesmir C, de Boer RJ. Can Selective MHC Downregulation Explain the Specificity and Genetic 
Diversity of NK Cell Receptors? Frontiers in immunol. 2015; 6:311.

103. Simova J, Pollakova V, Indrova M, Mikyskova R, Bieblova J, Stepanek I, Bubenik J, Reinis M. Immunotherapy augments the effect of 5-azacytidine on HPV16-associated tumours with different MHC class I-expression status. Brit J Cancer. 2011; 105:1533-1541.

104. Vlkova V, Stepanek I, Hruskova V, Senigl F, Mayerova V, Sramek M, Simova J, Bieblova J, Indrova M, Hejhal T, Derian N, Klatzmann D, Six A, Reinis M. Epigenetic regulations in the IFNgamma signalling pathway: IFNgamma-mediated MHC class I upregulation on tumour cells is associated with DNA demethylation of antigenpresenting machinery genes. Oncotarget. 2014; 5:69236935. doi: 10.18632/oncotarget.2222

105. Park J, Thomas S, Munster PN. Epigenetic modulation with histone deacetylase inhibitors in combination with immunotherapy. Epigenomics. 2015; 7:641-652.

106. Garrido F, Aptsiauri N, Doorduijn EM, Garcia Lora AM, van Hall T. The urgent need to recover MHC class I in cancers for effective immunotherapy. Current Opin Immunol. 2016; 39:44-51.

107. Demaria S, Golden EB, Formenti SC. Role of Local Radiation Therapy in Cancer Immunotherapy. JAMA Oncol. 2015; 1:1325-1332.

108. Klug F, Prakash H, Huber PE, Seibel T, Bender N, Halama N, Pfirschke C, Voss RH, Timke C, Umansky L, Klapproth $\mathrm{K}$, Schakel K, Garbi N, et al. Low-dose irradiation programs macrophage differentiation to an iNOS(+)/M1 phenotype that orchestrates effective $\mathrm{T}$ cell immunotherapy. Cancer Cell. 2013; 24:589-602.

109. Garnett CT, Palena C, Chakraborty M, Tsang KY, Schlom J, Hodge JW. Sublethal irradiation of human tumor cells modulates phenotype resulting in enhanced killing by cytotoxic T lymphocytes. Cancer Res. 2004; 64:7985-7994.

110. Waring P, Mullbacher A. Cell death induced by the Fas/ Fas ligand pathway and its role in pathology. Immunol Cell Biol. 1999; 77:312-317.

111. Siva S, MacManus MP, Martin RF, Martin OA. Abscopal effects of radiation therapy: a clinical review for the radiobiologist. Cancer Lett. 2015; 356:82-90.

112. Okuma K, Yamashita H, Niibe Y, Hayakawa K, Nakagawa K. Abscopal effect of radiation on lung metastases of hepatocellular carcinoma: a case report. J Med Case Rep. 2011; 5:111.

113. Postow MA, Callahan MK, Barker CA, Yamada Y, Yuan J, Kitano S, Mu Z, Rasalan T, Adamow M, Ritter E, Sedrak C, Jungbluth AA, Chua R, et al. Immunologic correlates of the abscopal effect in a patient with melanoma. New Engl J Med. 2012; 366:925-931.

114. Stamell EF, Wolchok JD, Gnjatic S, Lee NY, Brownell I. The abscopal effect associated with a systemic anti-melanoma immune response. Internat J Radiat Oncol, Biol, Phys. 2013; 85:293-295.

115. Barker HE, Paget JT, Khan AA, Harrington KJ. The tumour microenvironment after radiotherapy: mechanisms of resistance and recurrence. Nature Rev Cancer. 2015; 15:409-425.

116. Srikrishna G, Freeze HH. Endogenous damage-associated molecular pattern molecules at the crossroads of inflammation and cancer. Neoplasia. 2009; 11:615-628.

117. Mandal R, Chan TA. Personalized Oncology Meets Immunology: The Path toward Precision Immunotherapy. Cancer Discov. 2016; 6:703-713.

118. Sharma P, Allison JP. The future of immune checkpoint therapy. Science. 2015; 348:56-61.

119. Kamphorst AO, Wieland A, Nasti T, Yang S, Zhang R, Barber DL, Konieczny BT, Daugherty CZ, Koenig L, Yu K, Sica GL, Sharpe AH, Freeman GJ, Blazar BR, Turka LA, Owonikoko TK, et al. Rescue of exhausted CD8 T cells by PD-1-targeted therapies is CD28-dependent. Science. 2017; 355:1423-1427.

120. Hui E, Cheung J, Zhu J, Su X, Taylor MJ, Wallweber HA, Sasmal DK, Huang J, Kim JM, Mellman I, Vale RD. T cell costimulatory receptor CD28 is a primary target for PD-1mediated inhibition. Science. 2017; 355:1428-1433.

121. Vilgelm AE, Johnson DB, Richmond A. Combinatorial approach to cancer immunotherapy: strength in numbers. J Leuk Biol. 2016; 100:275-290.

122. Deng L, Liang H, Burnette B, Beckett M, Darga T, Weichselbaum RR, Fu YX. Irradiation and anti-PD-L1 treatment synergistically promote antitumor immunity in mice. J Clin Invest. 2014; 124:687-695.

123. Sharabi AB, Nirschl CJ, Kochel CM, Nirschl TR, Francica BJ, Velarde E, Deweese TL, Drake CG. Stereotactic Radiation Therapy Augments Antigen-Specific PD-1Mediated Antitumor Immune Responses via CrossPresentation of Tumor Antigen. Cancer Immunol Res. 2015; 3:345-355.

124. Wang X, Schoenhals JE, Li A, Valdecanas DR, Ye H, Zhang F, Tang C, Tang M, Liu CG, Liu X, Krishnan S, Allison JP, Sharma P, et al. Suppression of type I IFN signaling in tumors mediates resistance to anti-PD-1 treatment that can be overcome by radiotherapy. Cancer Res. 2016 (in press).

125. Golden EB, Demaria S, Schiff PB, Chachoua A, Formenti $\mathrm{SC}$. An abscopal response to radiation and ipilimumab in a patient with metastatic non-small cell lung cancer. Cancer Immunol Res. 2013; 1:365-372.

126. Tang C, Welsh JW, de Groot P, Massarelli E, Chang JY, Hess KR, Basu S, Curran MA, Cabanillas ME, Subbiah V, Fu S, Tsimberidou AM, Karp D, et al. Ipilimumab with stereotactic ablative radiation therapy: Phase I results and immunologic correlates from peripheral T-cells. Clin Cancer Res. 2017; 231:1388-1396. 
127. Twyman-Saint Victor C, Rech AJ, Maity A, Rengan R, Pauken KE, Stelekati E, Benci JL, Xu B, Dada H, Odorizzi PM, Herati RS, Mansfield KD, Patsch D, et al. Radiation and dual checkpoint blockade activate nonredundant immune mechanisms in cancer. Nature. 2015; 520:373-377.

128. Dewan MZ, Galloway AE, Kawashima N, Dewyngaert JK, Babb JS, Formenti SC, Demaria S. Fractionated but not single-dose radiotherapy induces an immune-mediated abscopal effect when combined with anti-CTLA-4 antibody. Clin Cancer Res. 2009; 15:5379-5388.

129. Chandra RA, Wilhite TJ, Balboni TA, Alexander BM, Spektor A, Ott PA, Ng AK, Hodi FS, Schoenfeld JD. A systematic evaluation of abscopal responses following radiotherapy in patients with metastatic melanoma treated with ipilimumab. Oncoimmunology. 2015; 4:e1046028.

130. Grimaldi AM, Simeone E, Giannarelli D, Muto P, Falivene S, Borzillo V, Giugliano FM, Sandomenico F, Petrillo A, Curvietto M, Esposito A, Paone M, Palla M, et al. Abscopal effects of radiotherapy on advanced melanoma patients who progressed after ipilimumab immunotherapy. Oncoimmunology. 2014; 3:e28780.

131. Golden EB, Formenti SC. Radiation therapy and immunotherapy: growing pains. Internat J Radiat Oncol, Biol, Physics. 2015; 91:252-254.

132. Le DT, Uram JN, Wang H, Bartlett BR, Kemberling H, Eyring AD, Skora AD, Luber BS, Azad NS, Laheru D, Biedrzycki B, Donehower RC, Zaheer A, et al. PD-1 Blockade in Tumors with Mismatch-Repair Deficiency. N Engl J Medicine. 2015; 372:2509-2520.

133. Rizvi NA, Hellmann MD, Snyder A, Kvistborg P, Makarov V, Havel JJ, Lee W, Yuan J, Wong P, Ho TS, Miller ML, Rekhtman N, Moreira AL, et al. Cancer immunology. Mutational landscape determines sensitivity to PD-1 blockade in non-small cell lung cancer. Science. 2015; 348:124-128.

134. Hiniker SM, Reddy SA, Maecker HT, Subrahmanyam PB, Rosenberg-Hasson Y, Swetter SM, Saha S, Shura L, Knox SJ. A Prospective Clinical Trial Combining Radiation Therapy With Systemic Immunotherapy in Metastatic Melanoma. Internat J Radiat Oncol, Biol, Physics. 2016; 96:578-588.

135. Johnson DB, Frampton GM, Rioth MJ, Yusko E, Xu Y, Guo X, Ennis RC, Fabrizio D, Chalmers ZR, Greenbowe J, Ali SM, Balasubramanian S, Sun JX, et al. Targeted next generation sequencing identifies markers of response to PD-1 blockade. Cancer Immunol Res. 2016.

136. Schumacher TN, Schreiber RD. Neoantigens in cancer immunotherapy. Science. 2015; 348:69-74.

137. Lugade AA, Moran JP, Gerber SA, Rose RC, Frelinger JG, Lord EM. Local radiation therapy of B16 melanoma tumors increases the generation of tumor antigen-specific effector cells that traffic to the tumor. J Immunol. 2005; 174:7516-7523.

138. Stronen E, Toebes M, Kelderman S, van Buuren MM, Yang W, van Rooij N, Donia M, Boschen ML, Lund-Johansen F, Olweus J, Schumacher TN. Targeting of cancer neoantigens with donor-derived $\mathrm{T}$ cell receptor repertoires. Science. 2016; 352:1337-1341.

139. Giannakis M, Mu XJ, Shukla SA, Qian ZR, Cohen O, Nishihara R, Bahl S, Cao Y, Amin-Mansour A, Yamauchi M, Sukawa Y, Stewart C, Rosenberg M, et al. Genomic Correlates of Immune-Cell Infiltrates in Colorectal Carcinoma. Cell Rep. 2016; 15:857-865:

140. Howitt BE, Shukla SA, Sholl LM, Ritterhouse LL, Watkins JC, Rodig S, Stover E, Strickland KC, D'Andrea AD, Wu CJ, Matulonis UA, Konstantinopoulos PA. Association of Polymerase e-Mutated and Microsatellite-Instable Endometrial Cancers With Neoantigen Load, Number of Tumor-Infiltrating Lymphocytes, and Expression of PD-1 and PD-L1. JAMA Oncol. 2015; 1:1319-1323.

141. Rosenberg JE, Hoffman-Censits J, Powles T, van der Heijden MS, Balar AV, Necchi A, Dawson N, O'Donnell $\mathrm{PH}$, Balmanoukian A, Loriot Y, Srinivas S, Retz MM, Grivas P, et al. Atezolizumab in patients with locally advanced and metastatic urothelial carcinoma who have progressed following treatment with platinum-based chemotherapy: a single-arm, multicentre, phase 2 trial. Lancet. 2016; 387:1909-1920.

142. Hugo W, Zaretsky JM, Sun L, Song C, Moreno BH, Hu-Lieskovan S, Berent-Maoz B, Pang J, Chmielowski B, Cherry G, Seja E, Lomeli S, Kong X, et al. Genomic and Transcriptomic Features of Response to Anti-PD-1 Therapy in Metastatic Melanoma. Cell. 2016; 165:35-44.

143. Riaz N, Havel JJ, Kendall SM, Makarov V, Walsh LA, Desrichard A, Weinhold N, Chan TA. Recurrent SERPINB3 and SERPINB4 mutations in patients who respond to antiCTLA4 immunotherapy. Nature Genet. 2016.48:1327-1329.

144. Gros A, Parkhurst MR, Tran E, Pasetto A, Robbins PF, Ilyas S, Prickett TD, Gartner JJ, Crystal JS, Roberts IM, TrebskaMcGowan K, Wunderlich JR, Yang JC, et al. Prospective identification of neoantigen-specific lymphocytes in the peripheral blood of melanoma patients. Nature Med. 2016; 22:433-438.

145. Alexandrov LB, Ju YS, Haase K, Van Loo P, Martincorena I, Nik-Zainal S, Totoki Y, Fujimoto A, Nakagawa H, Shibata T, Campbell PJ, Vineis P, Phillips DH, Stratton MR. Mutational signatures associated with tobacco smoking in human cancer. Science. 2016; 354:618-622.

146. Cancer Genome Atlas N. Genomic Classification of Cutaneous Melanoma. Cell. 2015; 161:1681-1696.

147. Govindan R, Ding L, Griffith M, Subramanian J, Dees ND, Kanchi KL, Maher CA, Fulton R, Fulton L, Wallis J, Chen $\mathrm{K}$, Walker J, McDonald S, et al. Genomic landscape of 
non-small cell lung cancer in smokers and never-smokers. Cell. 2012; 150:1121-1134.

148. Cancer Genome Atlas Research N. Comprehensive molecular profiling of lung adenocarcinoma. Nature. 2014; 511:543-550.

149. Mouw KW, Cleary JM, Reardon B, Pike J, Braunstein LZ, Kim J, Amin-Mansour A, Miao D, Damish A, Chin J,
Ott PA, Fuchs CS, Martin NE, et al. Genomic evolution after chemoradiotherapy in anal squamous cell carcinoma. Clinical Cancer Res. 2016 (in press). doi: 10.1158/10780432.CCR-16-2017. 